\title{
HENRY LAWES'S SETTINGS OF SONGS FOR MILTON'S “COMUS”
}

\author{
BY JOHN T. SHAWCROSS
}

Professor Shawcross, who received his doctorate from New York University, is on the faculty of the Department of English, Douglass College. A scholar of Renaissance literature, he is particularly interested in the work of John Milton.

I

$\mathrm{N}$ A former article on the manuscripts of John Milton's mask called "Comus" I drew attention to the fact that the texts of the songs for which music written by Henry Lawes exists are derived from revisions of the basic transcription in Milton's manuscript in the library of Trinity College, Cambridge. ${ }^{2}$ The songs come down to us in two manuscripts: British Museum Add. MS I I,5 I 8 (in an unknown hand) ${ }^{3}$ and the Lawes MS recently on loan to the British Museum (in Lawes's hand). ${ }^{4}$ The date of the basic transcription of the mask into the Trinity MS poses important questions for the music which Lawes wrote. Since the mask seems to have been transcribed in the autumn of 1637 , three years after the first performance on 29 September $1634{ }^{5}$ the music must have been revised

${ }^{1}$ See "Certain Relationships of the Manuscripts of Comus," Papers of the Bibliographical Society of America, LIV (1960), 38-56.

${ }^{2}$ Reproduced in facsimile by William Aldis Wright (London, 1899). Materials cited in this paper, with the exception of one manuscript of the songs, are available in the Rutgers University Library. Facsimiles of the mask in its three early editions $(1637,1645,1673)$ and of one of the songs manuscripts appear in Harris F. Fletcher's Milton's Poetical Works (Urbana, I943), Vol. I. Secondary works referenced here should be consulted for a fuller background in the textual problems concerned and for a cogent statement of the nature of Henry Lawes's composition. Partial reproduction of the second songs manuscript may be checked through the books listed in note 4 , all of which are among the Library's holdings.

${ }^{3}$ Reproduced in facsimile by Fletcher.

${ }^{4}$ One page facsimile (p. 68) is given in the standard biography of Lawes by Willa Evans (Modern Language Association, 1941) and in David Stevens's Milton Papers (Univ. of Chicago Press, 1927); see also H. J. Foss's edition of the songs in The Mask of Comus (London, I 937 ).

"See my discussions in "Certain Relationships," in "The Manuscripts of 'Comus': An Addendum," PBSA, LIV (1960), 293-294, and in "Speculations on the Dating of Materials in the First Part of Milton's Trinity MS," MLN, LXXV (1960), I I-17. Lines $231,860,962,963,972,1012$, and 1023 indicate that the songs postdate the manuscript transcription. 
to accord with the new words which furnish its texts. The musical settings in terms of the lines of the final text are: Song I, 976-983, 992-995, 998-999; Song 2, 230-243; Song 3, 859-866; Song 4, in two parts, 958-975; Song 5, IOI 2-IO23.

A collation of the British Museum MS of the five extant songs with the Lawes MS points up interesting variants. Textual differences between the Trinity MS and the manuscripts of the songs may be due to misreadings by transcribers: The British Museum MS gives "thy," 233 ("the"); "Pity," 24I ("Parlie"); "transplanted," 242 ("translated"); "o're," 965 (2) ("on"). The Lawes MS shows "thy," "parly" (corrected from something similar, but not "pity"), "transplanted," and "o're." Because of "Pity" in the British Museum MS, the Lawes MS could not have been derived from it. Musical variations in these song manuscripts may also be significant: The music of Song I in the British Museum MS has B-flat for the second syllable of "Hy-a-cinths" although the Lawes MS plainly shows an A. In Song 2 the British Museum MS has G and A for "her sad," but the Lawes MS gives A and C; "sweet," a tied half and quarter note in the former, is a half note and a quarter rest in the latter; the $G$ of "Pi-ty" is sharped in the latter's "Par-ly"; "Daugh-" is a tied quarter in the British Museum MS but a half note in the other; and the B-flat of "of" is sharped in the Lawes MS. This same copy repeats part one of Song 4 da capo, places the first note of the bass in a very odd position, and sustains "assays" by a half note and a quarter rest and "Praise" by a tied half note and a quarter note although the British Museum MS exactly reverses the phrasing of these rhyme words. The key signature of Song 5 is $\mathrm{F}$ major in the Lawes MS; however, the British Museum MS scribe omits a B-flat from each of its twelve staves, making the signature C major. "Me," B-flat in the Lawes MS, seems to be A in the British Museum MS. The bass accompaniment for the last four measures of Song $\mathrm{I}$ is found only in the British Museum MS. The foregoing may be errors of transcription or of omission; but the Lawes MS could not have derived from the British Museum MS, and the bass accompaniment in Song I suggests that the British Museum MS did not derive from the Lawes MS. What must therefore be concluded is that at least one intermediary and common musical and textual source lay between the Trinity MS and the extant songs manuscripts. 
The alterations from the basic Trinity MS transcription (given first) are: Song I-line 979, "plaine" > "broad"; two lines after 979 omitted and apparently rewritten as lines IOI4-IOI 5 ; line 982, "Atlas" > "Hesperus"; line 992, "garnish't" > "humid"; line 995, "watchet" > "purfl'd." Song 2-line 232, "by Mæanders" > "by slow Mæanders." Song 3-line 860, "Listen virgin where thou sit'st" $>$ "Listen where thou art sitting"; line 862 , originally different to rhyme with "sit'st" (perhaps something like "in twisted braids of flowers thou knit'st") > "in twisted braids of lillies knitting." Song 4-line 962, "of speedier toeing, \& courtly guise" > "of lighter toes \& such Court guise"; line 963 , "such as Hermes did devise" $>$ "as Mercury did first devise"; line 973, "bays" > "praise." Song 5line IOI I, "message well is" > "task is smoothly"; lines IOI4-IOI 6, perhaps added; line I023, "bow" > "stoope." Line 976 of Song I is given as "From the Heav'ns now I fly" to conform with its new position as prologue.

Variants of single words with the same number of syllables and the same stress may be disregarded. If we assume that the line recorded in the basic Trinity MS transcription was that used in 1634 (which it may not have been), remaining to be accounted for musically under a new dating for the Trinity MS are: (I) line 232 in Song 2; (2) line 860 in Song 3; (3) line 862 in Song 3; (4) line 962 in Song 4 ; (5) line 963 in Song 4; (6) the whole of Songs I and 5.

Line 232 in Song 2 requires an addition: the present D, D, C of "Shell by slow" (a quarter tone, an eighth rest, an eighth note, and a tied half and dotted quarter) would have been D, C (a whole tone, as is its rhyme word "well," and an eighth rest and a quarter note). The next line (860 in Song 3 ) fits perfectly and in fact is greatly improved by having the stressed "sit'st" fall on the dotted quarter note now corresponding to the unstressed "-ing." It is highly speculative to talk of an ur-line 862 , but if it was similar to that suggested above, the eighth notes A and B, given to "lillies," would support "flowers," if it was two syllables, or coalesce into a quarter note (A or B), if it was one syllable as it would be metrically. Again a quarter note would be given to a stressed syllable ("knit'st"), instead of to the weak feminine ending "-ing." Line 962 in Song 4 is also musically enhanced by Milton's "original" words. "Court" is slurred over two notes, which otherwise would represent "courtly." ("Speedier" is, 
of course, only two syllables, metrically or musically.) The fifth line for consideration does not contain the first unstressed syllable of the present line. This therefore requires that the notes now given to "Mercury did" (E, C, C, C), two eighths, a dotted quarter, and an eighth note, were instead three notes $(E, C, C)$, an eighth, a dotted quarter, and an eighth, and that the eighth note of present "first" was a quarter note for "did." Item six presents a different kind of problem.

The relationships between lines 976-999 and the fourteen or fifteen deleted lines after line 4 (cited as $4 a-40$ ), and between lines IOI4-IOI 5, found after line 979, and their rewritten form, found after line IOI3, must be examined because of their pertinency to Songs $\mathrm{I}$ and 5 . Line $4 \mathrm{~b}$ was repeated as line $4 \mathrm{a}$; Milton may have erred by putting down the line too soon or he may have been composing at this point as he wrote. An echo of this line reappears as 998 . Line $4 \mathrm{a}$ is metrically deficient in its first form. Its development seems to have been: "amidst the gardens Hespian" > interchange of the last two words $>$ "amidst th'Hespian gardens on whose bancks" > "amidst th'Hespian gardens where the banks" > return to the line immediately preceding. It is met again in lines $98 \mathrm{I}-982$. Lines $4 \mathrm{e}-4 \mathrm{~g}$ show up in copied lines 393-397 (note the transcribal error of "frite" for "fruite") and in line 983 . In addition other language of the deleted passage repeats itself in further lines of the epilogue. These recurrences in the epilogue of language and allusions found in lines $4 \mathrm{a}-4 \mathrm{o}$ are echoes rather than revised and reused material as shown by their appearance also in lines 393-397, which are in fact closer than is the epilogue. (The use of echoes can frequently be demonstrated, for example, between lines I 8 and ror 2.) "There," line 980, first written "the" with an " $r$ " squeezed in later, may evidence transcription of at least part of the epilogue. Composition can be seen in (I) the double appearance of lines ror4-IOI 5 (plus line IOI6) and (2) the line after 995, "watchet" in line 995 being deleted.

Perhaps what seems like an abbreviated text in Song I (the only song with lines in the Trinity MS missing) is the result of the use of early music but later words. In this case, the original epilogue may have been almost like the text of Song I, differences being noted before. Line 976 is not Milton's, being revised probably by Lawes so that the song could serve as a prologue. If the song as originally 
written (that is, as lines 976-999 with "To the Ocean now I fly") had been set by Lawes, the music must have been slightly different. The extant copies show a quarter rest after "Heav'ns." "Ocean" may have been sustained by the present $\mathrm{C}$ and this rest (another $\mathrm{C}$ ?) or by two other notes (two C's, a dotted quarter and an eighth?). The interchange of "Atlas," two syllables, and "Hesperus," two syllables metrically but represented here by three notes $(G, D, D)$, need detain us only a moment. Whether "Atlas" or "Hesperus," the line would be improved if there were but two notes $(G, D)$, as the next note ("and") is also D.

The lines found in the epilogue but not in the song may have been added at transcription. As mentioned before, line 995 must have been written during transcription because of the use of "watchet," originally in line 995. Lines 988-99 I and 996 seem to owe something to Spenser's description of the Garden of Adonis: ( I) "there æternall summer dwells" proceeds from Spenser's "eternal" period of flowering, stated and implied, and from "there is continuall spring, and harvest there continuall" ( $F Q$, III.vi.42); (2) the "myrtle alleys" are found in the "gloomy grove of mirtle trees" (III.vi.43); (3) the fragrant smells of balm, nard, and cassia approximate the "sweet gum," the "most dainty odours" which the ground gives off (III. vi.43). As the Garden of Adonis is the source of the additions in the further revision of the epilogue on p. 29 (lines 999-IOI I), there is reason to suppose that lines 988-99I and 996, apparently coming from the same description, date close to that revised epilogue, that is, in the fall or winter of I 637. (Incidentally, Spenser twice specifically called the Garden of Adonis a "paradise"; it is interesting that Milton, blending this garden with the paradisiacal Hesperian gardens, makes the beds of hyacinth and roses first found in the latter the place of Adonis's repose.) The reason for the entry of lines IOI4IOI 5 in both parts of the epilogue and the sequence of revision are indeterminant. Line IOI 4 after line 979 is metrically deficient though all other lines in the epilogue (except line 999) contain seven or eight beats. Perhaps "greene" was omitted through the problem of copying; perhaps the deficiency comes from faulty current composition. If the first couplet was transcribed, it may have been in a different position (perhaps after IOI 3 ) or in another worked-up version (which seems unlikely), in which case the second entry derives from the first. 
If it was not transcribed, then it was composed at writing, and the second usage was copied, with changes, from this first version. The couplet's present position does not seem to be the original one because of the changes from "cleere" to "low" to "slow," and the addition of "bow'd." Though it is indecisive, at least lines IOI4-I O 6 need not have been part of the original lines that became Song $\mathbf{I}^{6}{ }^{6}$

The second part of the epilogue, Song 5, if lines IOI4-IOI 6 were originally included, poses a musical question only in line IOI I. Though its rhythm is different from the present text, the line would fit the musical phrase exactly. As it now stands, "smooth" uses three notes as would "well." (The line underwent an intervening revision in the Trinity MS: "now my message well is don" $>$ "now my buisnesse is well don" > "now my task is smoothly don.") If lines IOI4-IOI 6 were not original, another couplet and a slightly different third line must have existed to accord with the music.

If the texts used in the extant songs were developed in 1637 as it seems, the music of those songs underwent revision sometime after that date. (The manuscripts certainly date after I634 as their headings show.) Not only was the accommodation of music to text possible, but what might have been the earlier music constitutes a superior wedding of music to text: ( I) the whole tone for both "shell" and "well" in Song 2; (2) the stressed dotted quarter falling on the stressed "sit'st" and "knit'st" in Song 3; (3) the lack of slurring over "court" in Song 4. It is well known that Lawes paid close attention to the text, and as Milton himself said, he "taught our English Music how to span / Words with just note and accent." This conclusion is corroborated in an unusual and provocative way: Lawes was not averse to changing music even some years later than the original composition in order to achieve accord with a changed text.

Why do we find music for only these five songs when at least two others occur in the mask (Sabrina's song, lines 890-899, and the

${ }^{6}$ The movement of Song $I$ to its position as prologue in the songs manuscripts and in the Bridgewater MS must postdate the deletion of lines $4 a-40$, for they would be too similar to be so close in position. When the Trinity MS copy of Comus was dated in 1634 , there was no problem. But a date of 1637 means that Song 1 could not have served as prologue at the first performance. Perhaps, in this case, the reason for its new position was simply the deletion of the passage after line 4 which Lawes had found effective. If so, Song I was probably part of the epilogue, forming a two-part musical ending with Song 5. According to the Lawes MS both songs are in the signature of $\mathrm{F}$ major. The British Museum signature of $\mathrm{C}$ major for Song 5 cannot be correct; see, for example, the ridiculous C, B-sharp, C for "of the moon." 
Shepherd's song, lines 922-937)? Probably because the single revision in the first is metrically equivalent to the earlier line, and because only two words in the second are altered, again by syllabic equivalents. In other words no musical change would have been necessary in these two songs. On the other hand musical change was necessary in the five extant songs to support the changed texts. The reason for the reproduction of the five songs may have been that Lawes (and others) wanted revised music to agree with the textual revisions of I 637.

The consequences of the conclusions of this paper are revision of our beliefs concerning the mask presented at the first performance in I634, awareness of the indefinitiveness of the music preserved, and further evidence of the methods of composition of both Milton and Lawes. The form of the mask and the music employed to greet the Earl of Bridgewater at his inauguration as Lord President of Wales are not certain despite the discussions offered over the years which assume such certainty. The "message" of the mask and its artistic accomplishments, disputed as they have been by critics, may depend upon what the "original" was like and what was added, deleted, and altered in the three years after the first performance. We see that the extant music, at best, only approximates the earliest songs and is probably incomplete. Interpretations of the mask without consideration of textual development are seen to be insubstantial by, for example, the analysis of Song I. Milton's epilogue has overtones of meaning and significance not present in its earliest version or in the version preserved in Song I, and this realization suggests a change in concept, or at least a clarification. The addition in the final version of Adonis and Venus as carnal lovers who languish far below the celestial heavens and, in contrast, of Cupid and Psyche as the legitimate union of heart and soul, which union brings forth Youth (eternal life) and Joy (heavenly bliss), must be considered in estimating the meaning of the poem today and in discussing the propriety of the work for the Earl's children to perform. Perhaps most directly significant as conclusion from this study of the songs, however, is the underscoring of Milton's frequent changing of text and apparent lack of satisfaction with his earlier work. When he goes so far as to alter that which has been set to music, music being an integral part of a mask, we may be assured that his approach to this mask (now really poem rather than dramatic work) and its thesis had altered in some way. 